\title{
Scale of Family Unpredictability During Childhood: Validity Evidence ${ }^{1}$
}

\author{
Anna Beatriz Carnielli Howat-Rodrigues \\ Universidade de São Paulo, São Paulo-SP, Brazil \\ Rosana Suemi Tokumaru² \\ Universidade Federal do Espirito Santo, Vitória-ES, Brazil
}

\begin{abstract}
The aim of this study was to examine evidence of validity for the Brazilian version of the Scale of Family Unpredictability during childhood. A total of 740 people participated in the study. The first sample was composed of 121 women over 40 years of age $\left(\bar{X}_{\text {age }}=5.86\right), 157$ adults in conflict with the law (148 men, $\left.\bar{X}_{\text {age }}=34.20\right)$, and 251 college students (122 men, $\left.\bar{X}_{\text {age }}=19.60\right)$. The second sample included 211 college students $\left(90 \mathrm{men}, \bar{X}_{\text {age }}=21.53\right)$. Exploratory and confirmatory analysis indicated that the three-dimensional model (nurturance, money, meals) presented a better goodness of fit, with satisfactory reliability indexes. A significant effect of all unpredictability factors on the purchasing power of the participants was found, confirming validity by contrasting groups of EIFI: people belonging to socioeconomic classes with lower purchasing power presented higher family unpredictability during childhood. We concluded that the three-dimensional EIFI is psychometrically adequate, allowing the differentiation of groups in the constructs evaluated.
\end{abstract}

Keywords: development, evaluation, childhood

\section{Escala de Imprevisibilidade Familiar na Infância (EIFI): Evidências de Validade}

\begin{abstract}
Resumo: Este estudo objetivou analisar evidências de validade da Escala de Imprevisibilidade Familiar na Infância (EIFI) para a população brasileira. Participaram 740 pessoas: na primeira amostra, 121 eram mulheres com mais de 40 anos de idade $\left(\bar{X}_{\text {idade }}=50,86\right), 157$ adultos em conflito com a lei (148 homens, $\left.\bar{X}_{\text {idade }}=34,20\right)$ e 251 universitários $\left(122\right.$ homens, $\left.\bar{X}_{\text {idade }}=19,60\right)$; na segunda amostra, 211 eram universitários ( 90 homens, $\bar{X}_{\text {idade }}=21,53$ ). As análises exploratória e confirmatória indicaram que o modelo tridimensional (cuidado/apoio, recursos financeiros, alimentação) foi o mais adequado para a EIFI, apresentando índices de confiabilidade satisfatórios. Verificou-se efeito significativo de todos os fatores de imprevisibilidade sobre o poder de compra dos participantes confirmando a validade por grupos contrastantes da EIFI: pessoas nas classes econômicas com menor poder de compra apresentaram maior imprevisibilidade familiar na infância. Concluiu-se que a EIFI tridimensional é adequada do ponto de vista psicométrico, permitindo diferenciar grupos nos construtos avaliados.
\end{abstract}

Palavras-chave: desenvolvimento, avaliação, infância

\section{Escala de Imprevisibilidad Familiar en la Infancia: Evidencia de Validez}

Resumen: Este estudio tuvo como objetivo analizar las evidencias sobre la validez de la Escala de Imprevisibilidad Familiar en la Infancia, dirigida a la población brasileña. Participaron 740 personas: en la primera muestra, 121 fueron mujeres con más de 40 años $\left(\bar{X}_{\text {idad }}=50,86\right), 157$ adultos en conflicto con la ley $\left(148\right.$ hombres, $\left.\bar{X}_{\text {idad }}=34,20\right)$ y 251 fueron universitarios (122 hombres, $\bar{X}_{\text {idad }}=19,60$ años); en la segunda muestra, 211 fueron universitarios (90 hombres, $\bar{X}_{\text {idad }}=21,53$ ). Los análisis exploratorio y confirmatorio indicaron que el modelo tridimensional (cuidado/apoyo; recursos financieros; alimentación) fue el más adecuado, mostrando índices de fiabilidad satisfactorios. Hay un efecto significativo de todos los factores de imprevisibilidad sobre el poder de compra de los participantes que confirman los grupos contrastantes de validez de la EIFI: personas con menor poder de compra presentaron mayor imprevisibilidad familiar en la infancia. Concluimos que la EIFI tridimensional es adecuada desde el punto de vista psicométrico, permitiendo diferenciar entre grupos en los constructos evaluados.

Palabras clave: desarollo, evaluación, infancia

The perception of environmental unpredictability is defined as the level of individual precision with which organisms predict the future availability of environmental resources and/or variation of periods in which there will be more or less environmental hostility (Ellis, Figueredo, Brumbach, \&

\footnotetext{
1 Support: Fundação de Amparo à Pesquisa e Inovação do Espírito Santo (FAPES).

2 Correspondence address:

Rosana Suemi Tokumaru. Universidade Federal do Espírito Santo. Centro de Ciências Humanas e Naturais. Departamento de Psicologia Social e do Desenvolvimento. Programa de Pós Graduação em Psicologia. Avenida Fernando Ferrari, 514. Goiabeiras. CEP 29075-91. Vitória-ES, Brazil. E-mail: suemitokumaru@gmail.com
}

Schlomer, 2009; Milliken, 1987). This perception may be related to different environments, such as physical, organizational, or family environments; the latter is the focus of this study.

Research has shown that one's perception of unpredictability in the family environment plays an important role in child development and affects individuals into adulthood (Brumbach, Figueredo, \& Ellis, 2009; Raley \& Wildsmith, 2004; Ross \& Hill, 2000). Brumbach et al. (2009) measured unpredictability in the childhood among adolescents and found direct effects on adult behavior, such as antisocial behavior and abnormally advancing through stages of life (e.g., having children). 
Ross and Hill (2000, 2002) suggest that individual unpredictability, formed during childhood and developed over time, favors the formation of a mental model of unpredictability, which comes to permeate one's individual perception concerning the availability of resources in the environment and precedes the individual's expectations of what will be available in the long and short runs. Family unpredictability refers to the level of inconsistency of parental behavior in fulfilling responsibilities, such as meeting children's basic needs.

Family unpredictability during childhood has been measured through questionnaires and scales. In general, questionnaires are composed of open questions in an attempt to investigate factors related to the perception of unpredictability, such as life expectancy, separation of parents and/or living with stepfather or stepmother, low socioeconomic level, constant changes (e.g. frequently moving or changing schools) and parents' delinquency (Albrecht \& Teachman, 2003; Brumbach et al., 2009; Capaldi, Crosby, \& Stoolmiller, 1996; Hill, Jenkins, \& Farmer, 2008; Hill, Ross, \& Low, 1997; Raley \& Wildsmith, 2004; Wang, Kruger, \& Wilke, 2009).

Scales have been developed to measure unpredictability in children's environment, both from the perspective of parents and their adolescent, young or adult children. Ross and Hill (1995) were the first to study unpredictability using scales. Initially, the authors developed a 5-point Likert scale $(1=$ totally disagree $;=$ totally agree $)$ to assess beliefs regarding unpredictability among young adults. The scale was composed of three statements: (a) I have a good idea about what is going to happen in my life; (b) Basically, the world is a predictable place; and (c) I know what to expect from people in my life. This scale presented a reliability coefficient (Cronbach's alpha) of .80 (considered satisfactory if above .70) (Nunnally, 1978; Pasquali, 2005).

Whileinvestigating theperceptions of parents concerning the unpredictability of their children's environment, Ross and Hill (2000) developed an instrument called the Family Unpredictability Scale (FUS), validated with an American sample. The authors asked parents of children 2 to 18 years old to complete a 5-point Likert scale and establish the extent of agreement with 198 items related to leisure, hobbies, money, routines, discipline, affection, physical needs, vacations, weekends, work, education and meals, applied to their children. The FUS resulted in an instrument of 23 items distributed into four factors: seven items in the discipline factor (discipline - parental inconsistency in establishing and maintaining rules), with a Cronbach's alpha of .85; seven items in the nurturance factor (nurturance - parental inconsistency in providing children's emotional needs comfort, protection, affection and supporting them while coping with stressful situations), with a Cronbach's alpha of .83 ; five items in the meals factor (meals - behavior related to uncertainty regarding mealtimes and who will participate in meals), with a Cronbach's alpha of .81; and three items in the money factor (money - uncertainty in regard to financial resources to cover expenditures and to buy goods), with a Cronbach's alpha of .79. Other definitions of factors are found in Ross and Hill $(2000,2002)$.

Alarcão and Gaspar (2007) conducted a study to validate the version of the FUS translated for the Portuguese population and found the same four factors, however, with a different distribution of items from the original factor solution. (The items, especially those in the Meals subscale, loaded better on the Money subscale). They also showed weaknesses concerning Cronbach's alpha scores, from satisfactory to moderate (.55 for the Meals factors, .77 for the discipline factor, .71 for affection or nurturance factor, and .70 for the money factor). The authors stress that a simple translation of the scales combined with the fact that participants were not randomly selected were factors that possibly contributed to these results. In relation to the translation of the scale, the authors suggest future studies to add new items in order to account for cultural diversity. This is relevant because validity, reliability, normalization and standardization should be ensured in different cultural contexts to enable generalizations (Erthal, 2001).

Interested in investigating the perceptions of young individuals concerning their childhood, Ross and McDuff (2008) adapted the FUS to verify perceptions of unpredictability in the family context during childhood, which resulted in the Retrospective Family Unpredictability Scale (R-FUS). This 5-point scale consisted of 28 self-reported items distributed into the same 4 factors already described for the FUS (discipline, meals, nurturance, and money). The factors discipline and nurturance, however, were divided into paternal discipline and maternal discipline, paternal nurturance and maternal nurturance, totaling 6 factors. The 5 items in meals unpredictability presented a Cronbach's alpha of .82; the three items in money unpredictability presented a Cronbach's alpha of .71; the six items in maternal nurturance factor presented a Cronbach's alpha of .80; the six items in paternal nurturance presented an alpha of .85; the four items in maternal discipline presented an alpha of .84; and the four items in paternal discipline presented a Cronbach's alpha of .73. The authors validated the scale for the American population and obtained satisfactory results.

Howat-Rodrigues, De Andrade and Tokumaru (2012) translated, adapted and validated the R-FUS (Ross \& McDuff, 2008) to Brazilian groups with different educational levels (undergraduates, individuals with bachelor's degrees, high school and middle school). Following the conclusion reached by Alarcão and Gaspar (2007), Howat-Rodrigues, De Andrade and Tokumaru tried to account for cultural and group diversities concerning family unpredictability in childhood, including items after the translation of the instrument and consulting participants of different social groups who contributed with different experiences concerning unpredictability. Since the instrument had the purpose of serving the Brazilian population and its diversity, 
they opted to group the items measuring affection and discipline separately for mothers and fathers. Hence, before the participants started answering the items, they were asked to write about the most significant people who cared for them during childhood and all the questions should be answered with these people in mind; the people could be either biological or foster parents, relatives, or institutions (e.g. orphanages), among other possibilities.

Based on this work, a final instrument was developed with 27 items assessed on a 5-point Likert scale and distributed into the four factors proposed by Ross and Hill (2000): 11 items in the nurturance factor, which explained $13.11 \%$ of the model and presented a Cronbach's alpha of $.88 ; 8$ items in the money factor, which explained $11.03 \%$ of the model and presented a Cronbach's alpha of $.85 ; 6$ items in the meals factor, which explained $6.95 \%$ of the model and presented a Cronbach's alpha of .80 ; and 2 items in the discipline factor, which explained $4.92 \%$ of the model and presented a Cronbach's alpha of .78. The instrument was considered valid for the Brazilian population and was called Escala de Imprevisibilidade Familiar na Infância (EIFI), (Scale of Family Unpredictability during Childhood); though similar to the FUS Portuguese version (Alarcão \& Gaspar, 2007), the distribution of items was different from the R-FUS original factor solution, with items in the Discipline subscale loading on the Nurturance subscale.

Some weaknesses were found in the EIFI's Brazilian version, such as the Discipline subscale, which provides little explanation for the model and the factor solution was different form the original model (R-FUS). This study's aim was to analyze evidence of the validity of the Escala de Imprevisibilidade Familiar na Infância (EIFI) directed to the Brazilian population, in order to advance in the exploratory study proposed by Howat-Rodrigues, De Andrade and Tokumaru (2012). Evidence of the validity of the internal structure was assessed based on exploratory factor analysis and confirmatory factor analysis. We also verified the validity of measures analyzing contrasting groups (Bartholomeu, Cecato, Montiel, Machado, \& Sisto, 2012; Sisto, Bartholomeu, \& Fernandes, 2005; Teixeira, Castro, \& Cavalheiro, 2008).

For the analysis of contrasting groups, we used differentiation based on purchasing power, which is an index used to classify populations into socioeconomic classes and is a proxy for income (Corseuil \& Foguel, 2002). Note that this index, in addition to other indicators like age and criminal involvement, functions as a predictor of family unpredictability during childhood so that the higher the purchasing power, the lower the indexes of child unpredictability (Howat-Rodrigues, Tokumaru, \& Izar, 2012).

Purchasing power in Brazil is established by the Brazilian Association of Market Research Companies (ABEP, 2008) based on the yearly survey performed by the Brazilian Institute of Public Opinion and Statistics (IBOPE) on social, demographic and economic data of Brazilian families in metropolitan regions. ABEP (2008) developed an instrument called the Brazilian Economic Classification Criterion (CCEB) that is composed of a list of durable goods, such as TVs, refrigerators, cars, and DVD players, among others; an item indicating whether the individual hires workers to perform domestic chores; and another item indicating the educational level of the head of the household. The respondent reports the quantity $(0,1,2,3,4$ or more) of items or workers present in the household and the educational level of the head of the household. Originally, the CCEB had a categorical format: (a) scores from 42 to 26 indicated Class A1; (b) scores from 35 to 41 indicated Class A2; (c) scores from 29 to 34, Class B1; (d) from 23 to 28, Class B2; (e) from 18 to 22 , Class $\mathrm{C} 1$; (f) scores from 14 to 17 indicated Class $\mathrm{C} 2$; (g) from 8 to 13 , Class $\mathrm{D}$; and (h) scores from 0 to 7 indicated Class E (ABEP, 2008). Therefore, in order to meet this study's aims, the purchasing power index was used to test the scale's ability to differentiate groups in terms of the specific domains of unpredictability.

\section{Method}

\section{Participants}

Initially, 529 people participated in the study. This first sample was part of a larger study addressing the relationship between family unpredictability during childhood and risk propensity. Afterwards, three groups of participants were selected according to characteristics indicated in the literature as being factors that influence the rates of risk propensity, such as age, being in conflict with the law, and sex (Daly \& Wilson, 2001, 2005; Ermer, Cosmides, \& Tooby, 2008; Hill et al., 1997; Steinberg, 2004; Wilson, Daly, \& Pound, 2002).

Of the 529 participants, 121 were women aged 5.86 years old on average $(S D=8.66)$. Most were married/cohabited $(n=76), 72$ had a bachelor's degree, and 49 had completed high school, with an average purchasing power of 28.48 $(S D=6.97)$. A total of 157 were adults in conflict with the law and most were male $(n=148)$ with an average age of 34.20 years old $(S D=1.19)$. Most were married/cohabited $(n=87)$, had primary school education $(n=103)$ and an average purchasing power of $17.89(S D=6.20)$. Finally, 251 were young college students with an average age of 19.60 years old $(S D=3.30)$. This sample was composed of 122 men and 129 women attending college. Most were single $(n=249)$, with an average purchasing power of $26.95(S D=8.12)$. All the participants lived in the state of Espírito Santo, Brazil.

A new collection of data was conducted with 211 young college students. A total of 105 participants lived in São Paulo, Brazil and 106 participants lived in Espírito Santo, Brazil. A total of 121 participants were women aged 21.60 years old on average $(S D=2.19)$, with an average purchasing power of $3.94(S D=7.39)$; 90 individuals were men aged $21.46(S D=2)$ on average, with an average purchasing power of $31.9(S D=7.45)$. 


\section{Instruments}

A socio-demographic questionnaire was used in both data collections and included questions addressing sex, age, schooling, criminal status (Are you responding to a criminal suit?), marital status, and purchasing power (CCEB). Statistically, CCEB was used in two different ways: (a) as a continuous measure for descriptive analysis, in which the participants could score from 0 to 46 points according to his/her answers; the higher the score the higher the consumption of goods and the educational level of the participant/family; and (b) as a categorical measure to analyze validity per group. Originally, the CCEB was used categorically, as previously described; however, based on the participants' analysis of frequency of distribution in eight categories originally proposed, we opted to use four categories based on the original classification, namely: (a) Class A, with scores from 35 to 46; (b) Class B, scores from 23 to 34; (c) Class C, scores from 14 to 22; and (d) Class D, scores from 0 to 13 .

The EIFI adapted and validated by Howat-Rodrigues, De Andrade and Tokumaru (2012) was also used. The inventory was composed of 27 items distributed in the following factors: nurturance, meals, money and discipline, as previously mentioned. The items were assessed on a 5-point Likert scale ( $1=$ totally disagree; $5=$ totally agree $)$. Items with negative factor loads are inverted and the items in each factor are totaled to obtain internal scores.

\section{Procedure}

Data collection. The first data collection was performed in one collective session (undergraduate students) and individual sessions (women and adults in conflict with the law), which took approximately 20 minutes. We worked with a convenience sample: adults in conflict with the law were recruited from a court setting with the judge's authorization; undergraduate students were recruited in classrooms with the authorization of professors; and women were recruited through the researchers' personal contacts. In the second data collection, the sessions were individual and participants were approached in universities, and people from the researchers' personal contacts. EIFI is a selfreported instrument. Its application, however, depended on the participants' level of education.

Data analysis. Data were analyzed using the Statistical Package for Social Sciences (SPSS), version 16.0 and Analysis of Moment Structures (Amos), version 7.0. First, descriptive analysis was performed with all the scale's items. For the sample of the first collection, the database was randomly divided (using the function to select random samples of cases in the SPSS) into two databases of the same size (approximately 50\% of cases were allotted to each database). The dimensional structure of the instrument was verified in part of the sample using exploratory factor analysis (EFA) and the Cronbach's alpha reliability indexes were computed for the items of the resulting subscales. Confirmatory factor analysis was used with the second part of the database, in addition to computing the reliability coefficients of the resulting subscales. For the sample of the second data collection, we performed the same procedures without, however, dividing the database.

The method of estimation to verify goodness of fit of the models proposed by CFA was Maximum Likelihood (ML). The following indexes were assessed according to the suggestions of Hair, Anderson, Thatam and Black (2006) and Pilati and Laros (2007): (a) $\chi 2$ (Chi-square) - goodness of fitness index; (b) $\chi^{2} / \mathrm{df}$ - adjusted indicator (values between 2 and 5 are recommended); (c) Comparative Fit Index (CFI) comparative indicator concerning goodness of fit of models (values above 90 are recommended); and (d) Root Mean Square Error of Approximation (RMSEA) - large sample residual analysis indicator (values below .08 with confidence interval of $90 \%$ are recommended).

For the comparative analysis between groups the multivariate analysis of variance (MANOVA) was used to verify aspects of validity per groups.

\section{Ethical Considerations}

This study complied with ethical guidelines and was approved by the Institutional Review Board at the Universidade Federal do Espírito Santo (No. 089/09). The authors informed the participants about the study's aims. Participants provided consent signing free and informed consent forms.

\section{Results}

\section{Exploratory Factor Analysis and Reliability Indicators}

With the first database $(n=258)$, we proceeded to the principal components analysis of the 27 items of the scale with the purpose of verifying the adequacy of the data matrix for the factor analysis procedure. It presented values that satisfied conditions for the factor procedure (Pasquali, 2005), with KMO of .819 and Bartlett's sphericity test resulting in 3915.921 ( $\mathrm{df}=780, p<.001)$. The initial number of factors suggested by the scree plot was four or five factors. We opted for the solution of four factors because it was in agreement with the theory's predictions (Howat-Rodrigues, De Andrade \& Tokumaru, 2012). Here, 11 items loaded on the factor called by HowatRodrigues, De Andrade and Tokumaru as nurturance (iac), eight items loaded on the money factor (irf), eight on the meals factor (ia), and two items loaded on the discipline factor (id). This initial solution explained $41.83 \%$ of data.

We opted for a gradual and systematic process to exclude items in order to find a better factor solution for the data matrix, considering the following criteria: (a) factor load equal or above .4; (b) test for items that presented high correlation (approximately .70) in the correlations matrix; (c) contribution of the item to the Cronbach's alpha of the factor (considered ideal > .70) (Nunnally, 1978; Pasquali, 2005); and (d) communality of the item (considered to be acceptable around .4) (Dancey \& Reidy, 2006). 
In summary, item irf7 did not achieve the desirable factor load and was excluded from the analysis. In the first factor, item iac1 presented high correlation with the items iac2, iac3, iac5, and was potentially functioning as a confounding item in the scale's indexes. For this reason, we opted to exclude it. For the same reason, item irf2 in the second factor was also excluded from the analysis. Item iac 10 was deleted because it worsened the Cronbach's alpha of factor 1; a fourth factor presented two items with high correlation among them; and finally, two items (ia6 and iac11) were excluded because they presented communalities around .20. In total, of the 27 initial items, eight were eliminated and 19 items remained in the definitive factor solution. These 19 items, extracted through the method of Principal Component Analysis, with varimax rotation, which was justified by the assumption of relationship of independence between the factors, presented a final factor solution of $\mathrm{KMO}=.835$ and Bartlett's sphericity test resulted in $1791.175(\mathrm{df}=171, p<.001)$.

The scree plot suggested that a solution with 3 or 4 factors was the most appropriate. For the final decision concerning the number of factors to be extracted we initially established two-factor structures, with 3 and 4 factors. The 4-factor structure presented items with a distribution different from the one based on Howat-Rodrigues, De Andrade and Tokumaru (2012). Additionally, we relied on the assumption of a 3-factor structure presented in the literature. Even though Howat-Rodrigues, De Andrade and Tokumaru assumed a 4-factor structure, the two items that composed the fourth factor were excluded from the analysis based on the exclusion criteria. This extraction explained $53.37 \%$ of the total variance in the data.

Table 1 presents the 19 items distributed into three factors, their respective communalities, quantity of items and variance explained by the factor and reliability indexes (Cronbach's alpha) of each in the principal axis factoring. Each factor was designated according to the general characteristic of the items, regardless of the dimensions to which they belonged before, resulting in the following categories: (a) nurturance (Factor 1), (b) Money (Factor 2), and (c) Meals (Factor 3).

Table 1

Extracted Factors (1 to 3), Factor Loads, Communalities ( $\left.h^{2}\right)$, Quantity of Items, Variance Explained for Each Factor and Reliability Indexes (Cronbach's alpha) of EIFI by the Principal Axis Factoring and Varimax Rotation

\begin{tabular}{|c|c|c|c|c|c|c|c|c|c|}
\hline \multirow[b]{3}{*}{ Code } & \multirow[b]{3}{*}{ Items } & \multicolumn{4}{|c|}{$\begin{array}{l}\text { First data collection } \\
\quad n=258\end{array}$} & \multicolumn{4}{|c|}{$\begin{array}{l}\text { Second data collection } \\
n=211\end{array}$} \\
\hline & & \multicolumn{3}{|c|}{ Factors } & \multirow{2}{*}{$\mathrm{h}^{2}$} & \multicolumn{3}{|c|}{ Factors } & \multirow{2}{*}{$h^{2}$} \\
\hline & & 1 & 2 & 3 & & 1 & 2 & 3 & \\
\hline iac2 & I was sure that my family would support me if I needed. & .80 & & & .67 & .76 & & & .60 \\
\hline iac3 & I knew my family would be there to take care of me. & .76 & & & .59 & .81 & & & .66 \\
\hline iac4 & I felt loved by my family. & .76 & & & .61 & .83 & & & .72 \\
\hline iac5 & I knew my family would be there to protect me. & .73 & & & .56 & .78 & & & .61 \\
\hline iac6 & Whenever I hurt myself, I knew I could count on my family to provide first aid. & .67 & & & .40 & $\mathrm{X}$ & & & $\mathrm{X}$ \\
\hline iac7 & I knew I was important for my family. & .66 & & & .48 & 67 & & & .46 \\
\hline iac8 & In my family, we cared for each other. & .65 & & & .45 & .70 & & & .44 \\
\hline iac9 & When I got my feelings hurt, I went to my mom for comfort. & .62 & & & .43 & .65 & & & .57 \\
\hline irf1 & $\begin{array}{l}\text { There were times when we did not have money to pay for basic needs } \\
\text { (toiletries, clothing, etc.) }\end{array}$ & & .85 & & .73 & & .78 & & .61 \\
\hline $\operatorname{irf3}$ & My family was never sure whether there would be food for daily meals. & & .77 & & 60 & & .63 & & .40 \\
\hline irf4 & $\begin{array}{l}\text { When I was a child, my family was never sure how we would pay our bills } \\
\text { from month to month. }\end{array}$ & & .68 & & .50 & & .66 & & .50 \\
\hline irf5 & Other children from my family and I had to start working early on. & & .67 & & .45 & & .51 & & .31 \\
\hline irf6 & $\begin{array}{l}\text { My family was always concerned that we would run out of food before we } \\
\text { could buy more. }\end{array}$ & & .66 & & .45 & & .60 & & .37 \\
\hline irf8 & $\begin{array}{c}\text { During my childhood, there were people in my family who became } \\
\text { unemployed. }\end{array}$ & & .57 & & .36 & & .50 & & .26 \\
\hline ial & Usually, dinner was served at the same time everyday. & & & .81 & 69 & & & .83 & .69 \\
\hline ia2 & Usually, lunch was served at the same time everyday. & & & .79 & .64 & & & .69 & .49 \\
\hline ia3 & $\begin{array}{c}\text { During my childhood, the same people sat down and ate dinner Monday } \\
\text { through Friday. }\end{array}$ & & & .77 & .51 & & & .71 & .54 \\
\hline ia4 & Meals at my home were at different times every day. & & & .67 & .61 & & & .83 & .74 \\
\hline \multirow[t]{4}{*}{ ia5 } & At my home I knew who would be present at meals. & & & .60 & .43 & & & .69 & .52 \\
\hline & Number of items & 8 & 6 & 5 & & 7 & 6 & 5 & \\
\hline & $\%$ of explained variance & 26.0 & 15.4 & 11.9 & & 26.1 & 11.4 & 15.0 & \\
\hline & Cronbach's alpha & .85 & .79 & .80 & & .85 & .63 & .83 & \\
\hline
\end{tabular}




\section{Confirmatory Factor Analysis and Reliability Indicators}

Aiming to verify the measure's structural stability as well as to verify the three-dimensionality of the construct of family unpredictability during childhood in the Brazilian sample, the second database was submitted to confirmatory factor analysis - CFA $(n=271)$. The model to be tested was the matrix that resulted from the exploratory study.

Goodness of fit of the initial hypothetical model was satisfactory in the original structure $[\chi 2=293.51, \mathrm{df}=149$ $(p<.001), \chi 2 / \mathrm{df}=1.97, \mathrm{CFI}=.91, \operatorname{RMSEA}(90 \% \mathrm{CI})=.060$ (.050-.070)]. High values, however, were found between the items' pairs of error parameter $(\mathrm{e} 17-\mathrm{e} 19=25.34)$. These values are obtained based on the suggestion to modify indexes. According to Hair et al. (2006), the researcher should use the modification of items as a guideline to improve the model and, even though it is assumed that no relationship among the errors exists, the test foresees that errors of items belonging to the same factor (also the case) and that they are theoretically similar (also the case presented, since the items concerning errors e 17 and e 19 - items ia 3 and ia5, respectively - were related to the same theme, [un]predictability of people being present or absent during meals), can be recommended for modified use. Therefore, we opted to establish co-variance among errors of the mentioned items, since their parameters were high and belonged to the same factor.

After testing the new model with this correction, we obtained the model proposed in Figure $1\left[\chi^{2}=266.107\right.$, $\mathrm{df}=148(p<.001), \chi 2 / \mathrm{df}=1.80$, CFI $=.93$, RMSEA $(90 \% \mathrm{CI})=.54(.044-.065)]$. Both in the model without correlation among errors and in the model with correlation between errors, goodness of fit $\left(\chi^{2}\right)$ was higher than the desirable level; however, in the model in which parameters of errors between the pairs e17-e19 was controlled for, the index decreased slightly. Goodness of fit $(\chi 2 / \mathrm{df})$ was close to two, which is acceptable. The CFI, which was already satisfactory, and remained satisfactory with a slight elevation. The RMSEA from the first model, also satisfactory, decreased slightly, improving the index. Analyses with and without control of errors will be considered for the structural confirmation with a new sample.

The reliability coefficients (Cronbach's alpha) of the measure in the second sample were: (1) Nurturance $($ iac $)=.84,(2)$ Money (ir) $=.81$, and (3) Meals (ia) $=.79$.

\section{Confirming Factor Structures Based on New Collection of Data}

Based on the sample from the second collection $(n=211)$, with the 19 items distributed into the three proposed factors, we proceeded to extract factors using Principal Component Analysis with varimax rotation $(\mathrm{KMO}=.795$; Bartlett's sphericity test $=1503.813 ; \mathrm{df}=171 ; p<.001$ ). One of the original items (iac6) did not load on any factor and its communality was low (.23). Therefore, we opted to exclude it and perform new analysis $(\mathrm{KMO}=.793$; Bartlett's sphericity test $=1454.383 ; \mathrm{df}=153 ; p<.001)$. This solution explained $52.55 \%$ of the total variance of data. The results are presented in Table 1.

The same database $(n=211)$ was submitted to CFA, and the model tested was the matrix that resulted from the exploratory study without the variable iac6. Without

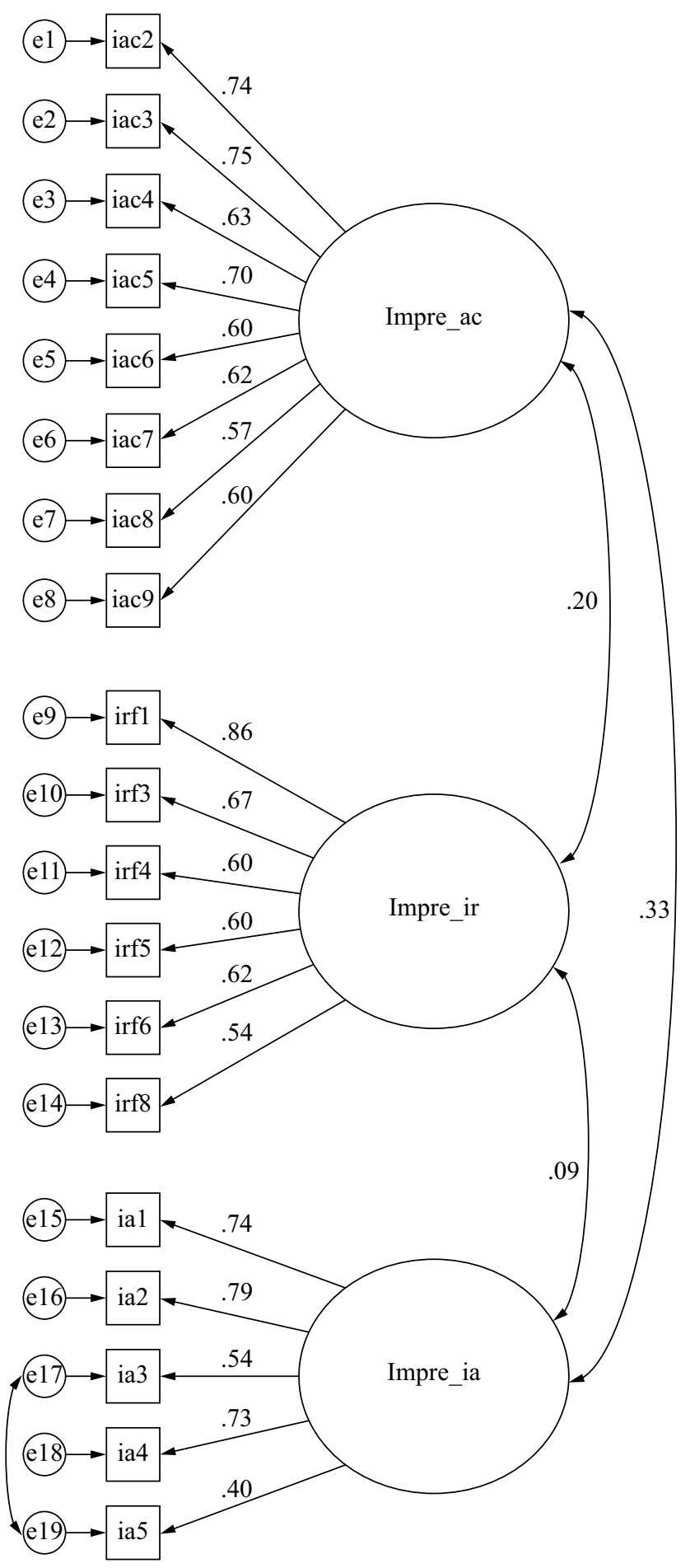

Figure 1. Three-factor model of EIFI obtained from a sample of 271 participants. Standardized estimates: regression coefficients close to unidirectional arrows and squared multiple correlations close to the variables. 
controlling for previous errors, expressed here as e16-e18 (25.343), goodness of fit indexes were $\left[\chi^{2}=341.08\right.$, $\mathrm{df}=133(p<.001), \chi 2 / \mathrm{df}=2.58, \mathrm{CFI}=.84$, RMSEA $(90 \% \mathrm{CI})=.087(.076-.098)]$. Controlling for the error values between the pairs of error parameters (e16-e18), similar to the model in the first sample, revealed that the indexes of the goodness of fit of the initial hypothetical model (CFI and RMSEA) were more satisfactory than without controlling for errors $[\chi 2=281.9, \mathrm{df}=131$ $(p<.001), \chi 2 / \mathrm{df}=2.15, \mathrm{CFI}=.89, \operatorname{RMSEA}(90 \% \mathrm{CI})=.074$ (.062-.086)]. Even though $\chi^{2}$ remained high in relation to the model of the first sample, the model of the second sample presented $\chi^{2} / \mathrm{df}$ better goodness of fit (Figure 2), while CFI and RMSEA remained satisfactory.

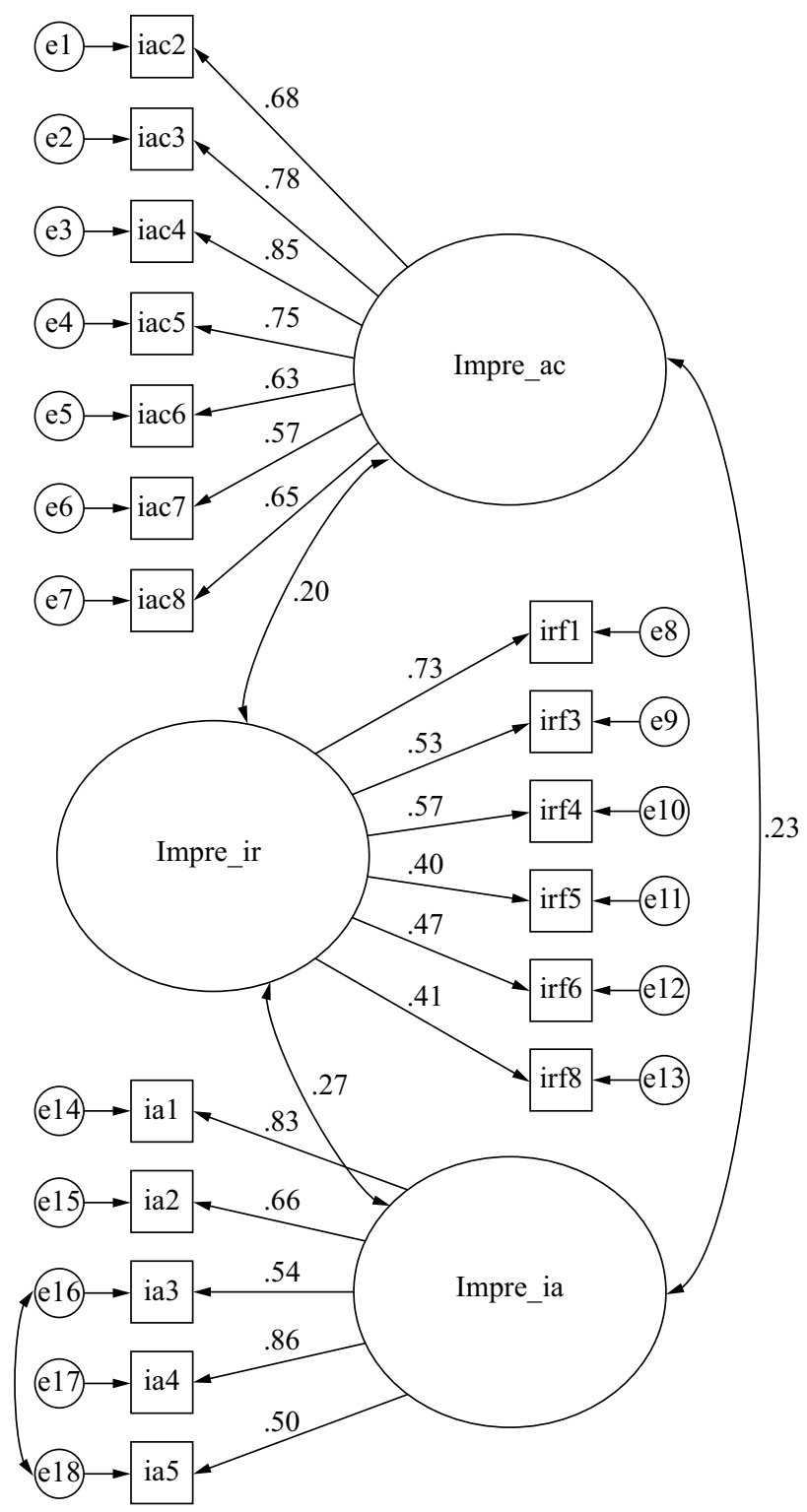

Figure 2. Three-factor model of EIFI obtained from a sample of 211 participants. Item iac6 was excluded. Standardized estimates: regression coefficients close to unidirectional arrows and squared multiple correlations close to the variables.

\section{Validity by Contrasting Groups}

In order to investigate the power of EIFI to differentiate the participants in regard to purchasing power (4 socioeconomic classes), the participants of the two data collections were gathered in a database totaling 740 participants. A MANOVA test was performed with three factors of family unpredictability during childhood, which evidenced significant differences for purchasing power in regard to all the dimensions of unpredictability $[F(9.1786)=22.46$; $p<.001$; Wilk's lambda distribution $=.770$ ], showing the instrument's ability to discriminate between groups. The values specific for each test were: Nurturance $[F(3.736)=7.60 ; p<.001]$, Money $[F(3.736)=65.62$; $p<.001]$ and Meals $[F(3.736)=3.90 ; p=.009]$.

Individuals with the highest purchasing power (Class A) presented low averages of unpredictability in all three factors compared to individuals belonging to Class B, who, in turn, presented averages of unpredictability lower than those in Class C, which in turn presented averages of unpredictability lower than individuals in Class D. In regard to the unpredictability of Nurturance, Class D $(M=1.92$; $S D=0.85)$ presented a higher average compared to Class A $(M=1.38 ; S D=0.44 ; \mathrm{d}=.80)$, Class B $(M=1.49 ; S D=0.70$; $\mathrm{d}=.52)$ and Class $\mathrm{C}(M=1.51 ; S D=0.65 ; \mathrm{d}=.51)$. In terms of Money unpredictability, all the classes were different from each other and obtained the following means: Class A $(M=1.62 ; S D=0.79)$; Class B $(M=2.19 ; S D=1.04)$; Class $\mathrm{C}(M=2.73 ; S D=1.11)$; Class D $(M=3.70 ; S D=0.89)$ $\left(\mathrm{d}_{\mathrm{AB}}=-.62 ; \mathrm{d}_{\mathrm{AC}}=-1.15 ; \mathrm{d}_{\mathrm{AD}}=-2.47 ; \mathrm{d}_{\mathrm{BC}}=-.50 ; \mathrm{d}_{\mathrm{BD}}=-1.56\right.$; $\left.\mathrm{d}_{\mathrm{CD}}=-1.09\right)$. In regard to Meals, Class $\mathrm{A}(M=2.01 ; S D=0.92)$ was different from Class $\mathrm{C}(M=2.31 ; S D=1.11 ; \mathrm{d}=-.29)$, which presented the lowest mean. The statistic $d$ refers to the effect size of Cohen's d, which is given in percentage of standard deviation. The higher $\mathrm{d}$ is, the stronger the effect of association between the pairs tested (Conboy, 2003). In the effect sizes presented, five suggested strong association $(\mathrm{d} \geq .8)$, four suggested average association $(\mathrm{d} \geq .5)$ and only one suggested weak association with $\mathrm{d}=.29$.

\section{Discussion}

The results presented in the exploratory and confirmatory procedures indicate a measure composed of three dimensions, those of Nurturance, Money and Meals, with satisfactory validity and reliability. Of the 27 original items proposed by Howat-Rodrigues, De Andrade and Tokumaru (2012), 19 were included in the initial factor solution. One item in the Nurturance subscale, however, presented statistical weaknesses when tested with the new sample and was excluded. Therefore, 18 items remained in the final factor solution and the dimensions were composed of seven, six, and five items, respectively, with satisfactory factor loads.

The final dimensionality of three factors differs from the dimensionality found in the exploratory study of EIFI by Howat-Rodrigues, De Andrade and Tokumaru (2012) and 
from the American scale by Ross and Hill (2000) and Ross and McDuff (2008), which proposed four dimensions: Nurturance, Money, Meals and Discipline. Even though the Discipline dimension was not included and nine items were excluded, this study is similar to the exploratory study of EIFI; that is, the current measure is also different from the distribution of items proposed by R-FUS (Ross \& Hill, 2000; Ross \& McDuff, 2008). This difference occurs mainly in regard to the Discipline subscale, which was excluded in this study's version, while some of its original items presented better factor solutions for the Nurturance factor. The Meals factor did not present satisfactory factor load in regard to breakfast (The same people used to gather for breakfast from Monday to Friday.).

Similarities with the EIFI exploratory study confer stability of items and factor structure to the instrument supporting the discussion of differences between the EIFI and R-FUS in cultural terms. The discussion of the meals dimension as a cultural habit is in agreement with the propositions of Batista Filho (1999), who considers meals to be a process influenced by various factors such as cultural and economic factors. According to Schluter (2003), breakfast, lunch and dinner are meals that stand out in western cultures. In regard to breakfast, for instance, there is an undeniable sociocultural influence on its meaning and nutritional composition. Breakfast can be a habit synonymous with healthy living, and may incorporate caloric or light foods. Breakfast for Americans seems to be more important, at least in energetic value, than among Brazilians, who tend to ingest fattier foods during lunch. This importance may be reflected in the EIFI meals subscale, in which the items concerning breakfast were not highlighted, a result that differs for the lunch and dinner items, which are presented in both the American (R-FUS) and Brazilian versions (EIFI).

Cultural differences may also have influenced the relationship between the Nurturance and Discipline subscales and the exclusion of the Discipline subscale in this study. Even in the exploratory study of EIFI, when Howat-Rodrigues, De Andrade and Tokumaru (2012) found a Discipline dimension composed of only two items, the authors discussed the importance of such a factor for the measure since discipline elements may be interpreted in the Brazilian context as belonging to the sphere of the care and support parents provide to their children. Additionally, this study found that in statistical terms, both the items composing this factor were highly correlated to each other: they were measuring the same construct within the dimension and presented low communalities, an index related to the measure's reliability. Therefore, we opted to withdraw this factor from the scale's Brazilian version.

The items of the other three remaining factors (Nurturance, Money and Meals) were in accordance with the description of Ross and Hill (2000): the items that composed the Nurturance dimension were related to parental inconsistency in meeting emotional needs and providing support in coping with stressful situations; the items that composed the Money factor were related to uncertainty concerning the provision of financial resources to pay for expenditures and goods; items in Meals were related to uncertainty concerning the time meals were served and who would participate in them. Taking into account cultural aspects and the measure's factor stability resulting from the exploratory analysis, the results presented here reflect the development of an appropriate, reliable and valid measure to be used in studies addressing family unpredictability during childhood, as well as other related themes.

Considering the differences in purchasing power, the results corroborate previous studies presenting groups with lower purchasing power (proxy of income) (Corseuil \& Foguel, 2002) or lower income, and also presenting higher levels of family unpredictability during childhood (Hill et al., 1997, 2008; Howat-Rodrigues, Tokumaru \& Tokumaru, 2012; Wang et al., 2009). Hence, EIFI followed the same discriminatory tendency, identifying social groups divided by purchasing power in all the unpredictability dimensions. Class A (higher purchasing power) presented the lowest averages of unpredictability in all the dimensions, Classes B and C (average purchasing power) presented intermediary averages of unpredictability, while the averages of Class B were lower than those presented by Class C and Class D (lowest purchasing power) presented the highest averages of family unpredictability during childhood in all the dimensions.

\section{Conclusion}

This study met its initial aim, which was to show the internal consistency and validity of EIFI by contrasting groups in a portion of the Brazilian population, showing a solution of three factors to be the most satisfactory. There are limitations in generalizing the study over the entire Brazilian population because, even though it addresses different socioeconomic classes, the study was conducted only in the Southeast region. Further studies applying the scale in different cultural groups of Brazilians from different states are needed to enable and strengthen generalization of the measure for the Brazilian population. In general, EIFI appropriately plays its role of measuring domains of family unpredictability during childhood (Pasquali, 2007).

\section{References}

Associação Brasileira de Empresas de Pesquisa. (2008). Critério de classificação de renda Brasil. Retrieved from http://www.abep.org/novo/FileGenerate.ashx?id=250

Alarcão, M., \& Gaspar, M. F. (2007). Imprevisibilidade familiar e suas implicações no desenvolvimento individual e familiar. Paidéia (Ribeirão Preto), 17(36), 89-102. doi:1.1590/S0103-863X2007000100009

Albrecht, C., \& Teachman, J. D. (2003). Childhood living arrangements and the risk of premarital intercourse. Journal of Family Issues, 24(7), 867-894. doi:1.1177/0192513X03252731 
Bartholomeu, D., Cecato, J. F., Montiel, J. M., Machado, A. A., \& Sisto, F. F. (2012). Teste de Bender (B-SPG) e DFH-Escala Sisto: Validade por grupos contrastantes. Estudos Interdisciplinares em Psicologia, 3(2), 241-257.

Batista Filho, M. (1999). Alimentação, nutrição \& saúde. In M. Z. Rouquayrol, \& N. Almeida Filho, Epidemiologia \& saúde (5th ed., pp. 353-374). Rio de Janeiro: Medsi.

Brumbach, B. H., Figueredo, A. J., \& Ellis, B. J. (2009). Effects of harsh and unpredictable environments in adolescence on development of life history strategies: A longitudinal test of an evolutionary model. Human Nature, 20(1), 25-51. doi:1.1007/s12110-009-9059-3

Capaldi, D. M., Crosby, L., \& Stoolmiller, M. (1996). Predicting the timing of first sexual intercourse for at-risk adolescent males. Child Development, 67(2), 344-359. doi: $1.2307 / 1131818$

Corseuil, C. H., \& Foguel, M. N. (2002). Uma sugestão de deflatores para rendas obtidas a partir de algumas pesquisas domiciliares do IBGE (Texto para Discussão $\mathrm{n}^{\circ}$ 897). Rio de Janeiro: IPEA.

Conboy, J. E. (2003). Algumas medidas típicas univariadas da magnitude do efeito. Análise Psicológica, 21(2), 145-158.

Daly, M., \& Wilson, M. (2001). Risk-taking, intrasexual competition, and homicide. In J. A. French, A. C. Kamil, \& D. W. Leger (Eds.), Evolutionary psychology and motivation (pp. 1-36). Lincoln, NE: University of Nebraska Press.

Daly, M., \& Wilson, M. (2005). Carpe diem: Adaptation and devaluing the future. Quarterly Review of Biology, 80(1), 55-6.

Dancey, C. P., \& Reidy, J. (2006). Estatística sem matemática para psicologia: Usando SPSS para Windows. Porto Alegre: Artes Médicas.

Ellis, B. J., Figueredo, A. J., Brumbach, B. H., \& Schlomer, G. L. (2009). Fundamental dimensions of environmental risk: The impact of harsh versus unpredictable environments on the evolution and development of life history strategies. Human Nature, 20(2), 204-268. doi:1.1007/s12110-009-9063-7

Ermer, E., Cosmides, L., \& Tooby, J. (2008). Relative status regulates risky decision making about resources in men: Evidence for the co-evolution of motivation and cognition. Evolution and Human Behavior, 29(2), 106-118. doi:1.1016/j.evolhumbehav.2007.11.002

Erthal, T. C. (2001). Manual de psicometria. Rio de Janeiro: Jorge Zahar.

Hair, J. F., Jr., Anderson, R. E., Thatam, R. L., \& Black, W. C. (2006). Análise multivariada de dados (5th ed.). Porto Alegre: Bookman.

Hill, E. M., Jenkins, J., \& Farmer, L. (2008). Family unpredictability, future discounting, and risk taking. Journal of Socio-Economics, 37(4), 1381-1396. doi:1.1016/j.socec.2006.12.081

Hill, E. M., Ross, L. T., \& Low, B. S. (1997). The role of future unpredictability in human risk-taking. Human Nature, 8(4), 287-325. doi:1.1007/BF02913037
Howat-Rodrigues, A. B. C., De Andrade, A. L., \& Tokumaru, R. S. (2012). Construção e validação da Escala de Imprevisibilidade Familiar na Infância (EIFI). Psicologia: Reflexão e Crítica, 25(2), 212-22. doi:1.1590/ S0102-79722012000200002

Howat-Rodrigues, A. B. C., Tokumaru, R. S., \& Izar, P. (2012). Childhood unpredictability and its relationship to sociodemographic data and future expectations (SFA). Paper presented at the Twenty-First Biennial Conference on Human Ethology, Vienna, Austria.

Milliken, F. J. (1987). Three types of perceived uncertainty about the environment: State, effect, and response uncertainty. Academy of Management Review, 12(1), 133-143.

Nunnally, J. C. (1978). Psychometric theory. New York: McGraw-Hill.

Pasquali, L. (2005). Extração dos fatores. In Análise fatorial para pesquisadores (pp. 55-86). Brasília: LabPam.

Pasquali, L. (2007). Validade dos testes psicológicos: Será possível reencontrar o caminho? Psicologia: Teoria e Pesquisa, 23(n ${ }^{\circ}$. spe.), 99-107.

Pilati, R., \& Laros, J. A. (2007). Modelos de equações estruturais em psicologia: Conceitos e aplicações. Psicologia: Teoria e Pesquisa, 23(2), 205-216. doi:1.1590/S0102-37722007000200011

Raley, R. K., \& Wildsmith, E. (2004). Cohabitation and children's family instability. Journal of Marriage and Family, 66(1), 210-219. doi:1.1111/j.0022-2445.2004.00015.x

Ross, L. T., \& Hill, E. M. (1995, June). Unpredictability schemas and problematic drinking. Paper presented at the meeting of the Research Society on Alcoholism, Steamboat Springs, CO.

Ross, L. T., \& Hill, E. M. (2000). The family unpredictability scale: Reliability and validity. Journal of Marriage and Family, 62(2), 549-562. doi:1.1111/j.1741-3737.200.00549.x

Ross, L. T., \& Hill, E. M. (2002). Childhood unpredictability, schemas for future unpredictability, and risk taking. Social Behavior and Personality, 30(5), 453-474.

Ross, L. T., \& McDuff, J. A. (2008). The retrospective family unpredictability scale: Reliability and validity. Journal of Child and Family Studies, 17(1), 13-27. doi:1.1007/s10826-007-9138-1

Schluter, R. G. (2003). Gastronomia e turismo. São Paulo: Aleph.

Sisto, F. F., Bartholomeu, D., \& Fernandes, D. C. (2005). Inteligência e conhecimento para conduzir veículos automotores. Psicologia: Pesquisa \& Trânsito, 1(1), 53-62.

Steinberg, L. (2004). Risk taking in adolescence: What changes, and why? Annals of the New York Academy of Sciences, 1021, 51-58.

Teixeira, M. A. P., Castro, G. D., \& Cavalheiro, C. V. (2008). Escalas de interesses vocacionais (EIV): Construção, validade fatorial e consistência interna. Psicologia em Estudo, 13(1), 179-186. doi:1.1590/S1413-73722008000100021 
Wang, X. T., Kruger, D. J., \& Wilke, A. (2009). Life history variables and risk-taking propensity. Evolution and Human Behavior, 30(2), 77-84. doi:1.1016/j.evolhumbehav.2008.09.006

Wilson, M., Daly, M., \& Pound, N. (2002). An evolutionary psychological perspective on the modulation of competitive confrontation and risk-taking. In D. W. Pfaff, A. P. Arnold, A. M. Etgen, S. E. Fahrbach, \& R. T. Rubin (Ed.), Hormones, brain and behavior (Vol. 5, pp. 381-408). San Diego: Academic Press.

Anna Beatriz Carnielli Howat-Rodrigues holds a Ph.D. from the Graduate Program in Experimental Psychology of the Instituto de Psicologia, Universidade de São Paulo.

Rosana Suemi Tokumaru is an Associate Professor of the Universidade Federal do Espírito Santo.

Received: Sep. $18^{\text {th }}, 2012$

$1^{\text {st }}$ Revision: Feb. $27^{\text {th }}, 2013$

Approved: Aug. 14 $4^{\text {th }}, 2013$

How to cite this article:

Howat-Rodrigues, A. B. C., \& Tokumaru, R. S. (2014). Scale of family unpredictability during childhood: Validity evidence. Paidéia (Ribeirão Preto), 24(57), 11-20. doi:10.1590/1982-43272457201403 